\title{
Tønnes Bekker-Nielsen. Urban Life and Local Politics in Roman Bithynia. The Small World of Dion Chrysostomos. (Aarhus: Aarhus University Press, Black Sea Studies 7, 2008)
}

\section{by Egill Arnarson}

What were politics like in a minor Greek province of the Roman Empire? In a community relatively remote from the caput mundi, how was Romes presence felt amongst the members of the political class? Did they endeavour to maintain the power of traditional local elites against parvenus who claimed to be on good terms with the Roman rulers?

These are some of the questions treated in Bekker-Nielsens study. Over the past six years, the Centre for Black Sea Studies at Aarshus University (pontos.dk) has published over a dozen of books, mainly collections of articles deriving from international conferences, on the most diverse topics within this field of research. It is interesting to note how unusually large the contribution of East European researchers is to these works, but given how logical this fact is, it should come as no surprise. Among these publications, the work Bekker-Nielsen co-edited on the $1^{\text {st. }}$ century philosopher-politician and rhetorician Dion Chrysostomos is of particular interest (Dion af Prusa. En grsk intellektuel mellem Rom og Sortehavet. Redigeret af Jesper Majbom Madsen \& Tnnes Bekker-Nielsen. Aarhus University Press 2007), since Dions life and works build the framework for the present study. Dion is however not the main topic in this work, but as its title suggests his small world, i.e. the city of Prusa and two of its neighboring cities and constant competitors, Nikaia and Nikomedia, in the small province of Bithynia, in the northwestern corner of Anatolia.

Most of Bekker-Nielsens book attempts to reconstruct the political institutions and social strata within which Dions career unfolds. Prior to this, however, he gives an overview of the textual and material sources left for undertaking such a research and tries to answer, inter alia, the question concerning the determining factors for the location of these Bithynian cities. Increased archeological research could lead to more definite results on these matters and it is therefore alarming to read that time is running out, and in the ever-expanding suburbs housing estates and industrial plants are obliterating all surface traces of ancient habitation and rendering systematic archeological survey impossible. (32).

Central to this study are two chapters on the political institutions and the political class in Bithynia. On the one hand, every named institution or function of political or more symbolic nature is deciphered, as much as the sources allow. Thereafter, Bekker-Nielsen present four levels of participation in political life in Bythinia the local, urban, regional and imperial levels and specifies which offices they generally 
included. To note is that the Roman franchise turns out to have been a determining factor for (free-born, male) Bithynians in order to aspire for a career above the local level.

In the only chapter specially focused on Dion Chrysostomos, the structures analyzed in the preceding chapters come to life: the tensions inherent in the socio-political system of the Bithynian province become manifest as Dion tries to follow his ambitions and make the best out of his somewhat problematic relation to Prusas wealthy upper class (126), due to his peregrine origins and his status as a champion of the dems (131). Bekker-Nielsens intention in this chapter is to write Dions political biography and, thus, he is mostly interested in the municipal speeches of his surviving 80 orations. These, however, prove to be of various kinds and contain e.g. Dions proposal of putting an end to the never-ending competition between Prusas neighbouring cities through the hopelessly sophistical solution of proclaiming both of them as first cities of the province (123).

Despite being quite vivid, the image presented of Dion does not leave the reader satisfied. In Dion af Prusa. En grsk intellektuel mellem Rom og Sortehavet (cf. 100101), one notices that Dion put forward some political views, e.g. on the nature of the good state. Are we to believe that such ideas have no relevance for appraising Dion as a politician? Perhaps this is the case, but a question of this sort is not considered by the author. One thus wonders whether the approach chosen in this work is not unnecessarily limited.

In the last two chapters, Bekker-Nielsen resumes what is known of Nikaias and Nikomedias fate until the $4^{\text {th }}$ century, before engaging in a broader speculation on the principles upon which political life in ancient cities was grounded. By confronting recent theories on the relation between governing and governed citizens (168) with what we are able to gather about politics in Roman Bithynia, he shows how they only partially succeed in describing the historical reality. There are manifest differences in the political culture of then and today, e.g. neither wealth nor acquaintance with famous performers (e.g. actors or gladiators) seems to have been factors that brought one much honour.

Yet, there are some remarkable similarities: urban financing methods in Roman times seem to have been astonishingly similar to the ones used nowadays, since [a]part from taxes, bequests and endowments, a city would draw some revenue from its landholdings, from the lease of public property (e.g., market stalls, grazing rights on public land) and from interest on capital. (70) Just as well, some issues of municipal politics reveal themselves as much older than one could expect: when Dion decides, as part of his new city centre project for Prusa, to have an old smithy torn down in order to be able to build a more fashionable colonnade, he has to face harsh public criticism because of the smithys historical and/or sentimental value (126-7). As Bekker-Nielsen pointedly asks: Perhaps ancient local politics were, after all, not that different from todays? (173). 
Egill Arnarson (b. 1973) studied Philosophy at the University of Iceland and University of Rennes 1 and is an M.A. in Philosophy, History and Latin from the Christian-Albrecht University in Kiel (2004), his final dissertation dealing with liberal cosmopolitanism within global ethics. He has taught Medieval Latin at the University of Iceland and Methodology at the Reykjavik University and has translated various texts of Philosophy and Human sciences into Icelandic. He currently works as a secretary for MPs at the Secretariat of Althingi. 